DOI 10.4467/2543733XSSB.20.001.12194

\title{
JÓZEF BECK O SWYCH PARTNERACH ZAGRANICZNYCH ORAZ W ICH OCZACH
}

\author{
Józef Beck about his Foreign Partners and in Their Eyes
}

Summary

The article deals with the opinions of Józef Beck on his foreign partners and the perception of his personality in the eyes of foreign political and diplomatic spheres. The text was created in connection with the biography of the Polish minister of foreign affairs prepared by the author (together with Prof. Mariusz Wołos). As a politician, he was an extremely controversial person. Due to his policy, he aroused dislike especially in Paris, Moscow and Prague. Many assessments devoted to him have been preserved, which is confirmed by sources. There are many reflections about his personality, and many sources testify to a dislike towards him. He was attributed to excessive ambitions, a kind of arrogance and excessive self-confidence and prejudice against France. Beck's opinions about his foreign partners are not very numerous, and in any case few of them are confirmed by sources. He did not particularly value his Central European (regional) colleagues: Benesz and Titulescu. Beck undeservedly gave high marks to the foreign ministers of the Western powers: Eden and Delbos. He trusted Swedish Minister Sandler and Romanian Victor Antonescu very much. An analysis of foreign opinions about Beck and his own judgements about his partners seriously supplements our knowledge of his seven years of work as a Polish minister of foreign affairs in the turbulent time of the international crisis that took place in Europe in the years 1933-1939.

Keywords: Poland 1918-1939, Józef Beck, international relations, images and stereotypes

Słowa kluczowe: Polska 1918-1939, Józef Beck, stosunki międzynarodowe, wizerunki i stereotypy

Sprawą bardzo złożoną i sporną jest wyważenie, w jakim stopniu polityka prowadzona przez poszczególne państwa zależy od woli i umiejętności jednostek ją kształtujących, a jak dalece jest zdeterminowana przez siły sprawcze. Jednak nie ma wątpliwości, że każdą politykę tworzą ludzie. Tak czy inaczej, „,wszystko na świecie robią ludzie” - zauważył 
minister Beck ${ }^{1}$. Zatem jak postrzegał ludzi, których spotkać mu przyszło w karierze politycznej na stanowisku ministra spraw zagranicznych i jak był przez nich widziany? Oto dwa pytania, wokół których warto się zatrzymać, studiując biografię tego polityka².

\section{I.}

Jako polityk Beck przede wszystkim spotkał na swej drodze Adolfa Hitlera. Rozmawiał z nim pięciokrotnie ${ }^{3}$. Nie wydaje się, aby był pod osobistym jego urokiem, niemniej na pewno z powagą słuchał długich zazwyczaj wywodów wodza III Rzeszy. Czy zatem ufał w jego zapewnienia? - jak uważał Stanisław Stroński, krytycznie komentując jego politykę ${ }^{4}$.

Błędem zasadniczym była nadmierna wiara Becka w szczerość Hitlera i w możność naprawdę trwałego zwrotu w stosunkach polsko-niemieckich. Strona polska nie rozumiała, że czasowa ugoda $z$ Polską jest Hitlerowi potrzebna tylko ze względów taktycznych i że nie może trwać długo przy niewątpliwym dalszym istnieniu w Rzeszy apetytów ekspansjonistycznych. Złudna i krótkowzroczna była nadzieja, że uwaga Niemiec zwróci się po rezygnacji z ekspansji w kierunku wschodnim, na południe i że tam zaabsorbowane Niemcy będą musiały trwale zrezygnować z polskiego Pomorza, Gdańska i Śląska

- pisał Henryk Batowski 5 .

W naszym przekonaniu potrzebne jest tu jedno rozróżnienie. Czymś innym jest ufać komuś bezwzględnie - i zdawać się na jego wolę, a czymś innym przyznawać pewien kredyt zaufania do słów, które w polityce wprawdzie nie zastępują czynów, ale bez nich obejść się ona nie może. W enuncjacjach Hitlera tkwiło wielkie novum w ustosunkowaniu do Polski i wyrażało się zerwanie z dziedzictwem niemieckiej „,negatywnej polityki polskiej”.

Dostrzegając to novum i zerwanie, Beck podchodził do wypowiedzi wodza III Rzeszy z niewątpliwym kredytem zaufania, zwłaszcza w latach 1934-1935. Przyjmował to jego podejście do Polski, gdyż zdawało się zrywać z tym wszystkim, co wytworzyło odwieczny antagonizm polsko-niemiecki. Łatwo dzisiaj w takim nastawieniu polskiego ministra dopatrywać się naiwności albo hołdowania złudzeniom. Chociaż z perspektywy roku 1939 taka ocena jest zasadna, należy pamiętać, że uderzenie przez Hitlera w nowy ton dyskursu wobec Polski zdawało się nieść jakieś nadzieje. Poza tym nie wolno zapominać, iż niemiecki Führer jawił się jako wiarygodny mąż stanu w oczach wielu polityków europejskich. Beck nie był w swych zapatrywaniach odosobniony.

Nowatorstwo totalitarnego ekspansjonizmu oraz jego dynamika były dla europejskich elit politycznych ówczesnej doby na ogół niezrozumiałe. I również w tej kwestii Beck nie

${ }^{1}$ J. Beck, Wspomnienia o polskiej polityce zagranicznej 1926-1939, oprac. A. M. Cienciała, Warszawa-Kraków 2015, s. 75.

${ }^{2}$ Biografię ministra pisałem w ostatnim czasie wspólnie z prof. Mariuszem Wołosem. Tekst w postaci dwutomowej książki oczekuje na edycję w Wydawnictwie Literackim w Krakowie. Rozważania niniejsze powstały w związku z tą książką.

${ }^{3}$ W okresie między lipcem 1935 r. a styczniem 1939 r.

${ }^{4}$ S. Stroński, Wierność Józefa Becka, ,Wiadomości”, 27 kwietnia 1952 r.

${ }^{5}$ H. Batowski, Między dwiema wojnami 1919-1939. Zarys historii dyplomatycznej, Kraków 1988, s. 207.

${ }^{6}$ Określenie ,negative Polenpolitik” stworzył historyk niemiecki Martin Broszat w książce Zweihundert Jahre deutsche Polenpolitik, Frankfurt/M. 1981 (wyd. 1, 1963). 
był w żaden sposób wyjątkiem. Bezprecedensowy fenomen ruchów i ustrojów totalitarnych przyniósł powszechne zaskoczenie, głównie swoją dynamiką, głębokością wpływu ideologii na życie i maksymalizmem ideologicznych celów. Beck wiele mówił o wspomnianej dynamice państw totalitarnych, podkreślał też wielką rolę ideologii w ich funkcjonowaniu, niemniej w myśleniu o tych sprawach nie wykraczał poza horyzont swoich czasów.

Wszystkie dostępne źródła pokazują, że choć Beck wierzył w rzetelność zapewnień Hitlera, to później był jednak również pierwszym politykiem w Europie, który zauważył zbrodniczy ekspansjonizm III Rzeszy. Po Monachium dostrzegł ekspansjonizm niemiecki z całym realizmem i zrozumiał, że dyktator ten, utraciwszy miarę rzeczy, liczy się tylko z językiem siły.

Wspomnienie antypolskiej polityki Lloyd George'a podczas paryskiej Konferencji Pokojowej (1919) było pierwszym akordem spotkania polityków Polski Odrodzonej z politykami Wielkiej Brytanii jako mocarstwa światowego. W 1935 r. Piłsudski rozmawiał o tym z ministrem Edenem, wypominając politykę Lloyd George'a. Beck postępował podobnie ${ }^{7}$.

Nie najlepsze doświadczenia - i to najdelikatniej mówiąc - miał Beck z brytyjskim ministrem spraw zagranicznych Johnem Simonem, który kierował dyplomacją brytyjską w pierwszych latach sprawowania funkcji ministerialnej przez polskiego polityka. Simon pojmował sprawy międzynarodowe jako legal causes $^{8}$. Na pewno jego zaangażowanie w sprawę paktu czterech mocarstw, proniemieckie stanowisko w kwestiach Wolnego Miasta Gdańska i ogólna niechęć do Polski jako kraju przynoszącego Europie problemy - mocno zaciążyły na relacjach obydwu polityków. Ze spotkań z Simonem zapamiętał Beck przede wszystkim ,nieprzyjemny ton” w rozmowach".

Pomyślniej ukształtowały się stosunki Becka z krótkotrwałym następcą Simona, Samuelem Hoarem, który w Foreign Office reprezentował „starą gwardię” polityczną. Beck cenił go za ,,szerokość poglądów” i zapewne również z powodu zabiegów wokół poprawy stosunków Londyn-Rzym, do czego polski minister przykładał dużą wagę.

Z prawdziwym zachwytem wypowiadał się Beck o Edenie. Miał powiedzieć, iż ma wrażenie, jak bardzo inne byłyby stosunki Polski z Francją, gdyby wśród Francuzów znalazł sie polityk o zdolnościach Edena ${ }^{10}$. Beck osobiście lubił go, mimo różnic w zapatrywaniach politycznych, byli in excellent terms - jak ują to ambasador Kennard. To dało brak pompousness i the sympathy dwóch mężczyzn w tym samym wieku, którzy walczyli w ostatniej wojnie. Ambasador przypuszczał jednak, że Eden nie miał złudzeń co do szczerości Becka ${ }^{11}$. Polski minister cenił Edena, gdyż wydawało mu się, iż z nim ,potrafił znaleźć wspólny język” i „uważał go niemal za przyjaciela”12. Wbrew opinii Kennarda, w ich relacjach ważne wydawało się głównie to, że Eden podobnie jak Beck był kombatantem I wojny światowej. Jednak po listopadzie 1936 r. „uprzejmość” brytyjskiego poli-

\footnotetext{
${ }^{7}$ Rozmowa z Edenem w Genewie 11 października 1935; sprawozdanie konsula brytyjskiego w Genewie dla Foreign Office (jw.).

${ }^{8}$ Sformułowanie Franka Robertsa, Dealing with Dictators. The Destruction and Revival of Europe 1930-1970, London 1991, s. 11.

${ }^{9}$ J. Beck, Wspomnienia o polskiej polityce zagranicznej 1926-1939, s. 146.

${ }^{10}$ Kennard do Simona, raport z 6 kwietnia 1935, TNA, Foreign Office 371, 18899, C. 3042/3042/55.

${ }^{11}$ Kenanrd do Sargenta, list z 8 marca 1938, TNA, Foreign Office 371, 21807, C. 1739/1320/55.

${ }^{12}$ P. Starzeński, Trzy lata z Beckiem, Warszawa 1991, s. 19.
} 
tyka do polskiego ministra ,poczęła zresztą stygnąć” - jak zauważył Edward Raczyński w swoim Dzienniku ${ }^{13}$.

W rozmowie z polskim ministrem w Monaco w roku 1937 brytyjski polityk ,z całym naciskiem podkreślił, że w Anglii epoka poglądów na Polskę, jej rolę i znaczenie pochodzące z czasów Lloyd George’a, skończyła się definitywnie (...)”. W swoich wspomnieniach poświęcił mu kilka pełnych wielkiego uznania zdań:

Eden, przedstawiciel młodego pokolenia konserwatystów, kapitan Strzelców Królewskich z czasów wojny, podchodził do spraw europejskich z umysłem nieobciążonym uprzedzeniami starego pokolenia angielskiego. Polityki uczył się już na nowej mapie Europy i używał języka prostszego, właściwego żołnierzom. Mimo że popularność swoją w Izbie Gmin w znacznym stopniu opierał na oxfordzkiej skłonności do teoretyzowania w polityce międzynarodowej, a w Genewie, nawet ze strony elementów lewicowych, respektowany był jako najwierniejszy z wiernych wobec Paktu Ligi, to w każdym razie jako człowiek wniósł do rozmów politycznych atmosferę wielkiej rzetelności i w praktyce, zwyczajem angielskim, stosował tyle doktryny, ile było trzeba dla interesów Imperium ${ }^{14}$.

Przebijający z tych słów entuzjazm nie był niestety odwzajemniony.

Stereotypowe wyobrażenie Becka, propagowane w Europie przez jego przeciwników, odwoływało się do zmyślonej historii o jego szpiegowskiej przygodzie we Francji, kiedy służył na stanowisku attaché wojskowego. Ambasador francuski Laroche miał mówić swemu koledze, iż minister nie może zapomnieć swego wydalenia z Francji, a kiedy tylko Piłsudski nie wnika w detale polityki zagranicznej swego kraju, staje się ona antyfrancuska. $\mathrm{Z}$ powodu tego epizodu Beck miał być silnie proniemiecki i antyfrancuski ${ }^{15}$.

Rzeczywistość oczywiście była inna. „Chociaż Piłsudski nie był frankofobem, zachował uraz do Francji, zbyt często postępującej jak nazbyt surowy nauczyciel i protektor"16. To klarowne i trafne stwierdzenie Wandycza godzi się nie tylko przypomnieć, ale wolno je również rozciągnąć na osobę Becka, gdyż jego zapatrywania na stosunki z Francją były identyczne.

Jeśli chodzi o relacje z Francuzami, to Beck w swojej karierze spotkał w randze ministrów przede wszystkim Barthou i Lavala, a także Flandina, Bluma i Delbosa. Nie miał sposobności załatwiać żadnych spraw z najbardziej znaczącym politykiem francuskim lat dwudziestych, Aristidem Briandem, który cieszył się wielkim uznaniem jako współtwórca Locarna i laureat pokojowej Nagrody Nobla.

Trzeba dostrzec u Becka niemałe uznanie dla Barthou, chociaż podzieliła ich sprawa Paktu Wschodniego. Nie ma wątpliwości, że postrzegał go jako męża stanu, a takich Francja międzywojenna nie miała wielu ${ }^{17}$. Jeśli pominąć Barthou i Brianda - którego oceniał wysoko mimo przekonania o szkodliwości systemu lokarneńskiego dla Polski - ogólnie

${ }^{13}$ E. Raczyński, W sojuszniczym Londynie. Dziennik ambasadora Edwarda Raczyńskiego 1939-1945, Warszawa 1990, s. 16 (notatka z końca 1936 r.).

${ }^{14}$ J. Beck, Wspomnienia o polskiej polityce zagranicznej 1926-1939, s. 128.

${ }_{15}$ AWP RF, f. 5, op. 15, pap. 109, dok. 68; Dniewnik Dawtiana, notatka z 21 stycznia 1935 (słowa Laroche'a).

${ }^{16}$ P. Wandycz, Polska wobec lokarneńskiej polityki Brianda, [w:] idem, Z dziejów dyplomacji, Londyn 1988, S. 86 .

${ }^{17}$ Był to „duży gracz, ale bez szczęścia” - tak ocenił go na wieść o śmierci 9 października 1934 r. marszałek Piłsudski (Kalendarium życia Józefa Piłsudskiego, t. IV, s. 379). 
polski minister nisko szacował francuską klasę polityczną. Karuzela ministerialna, czyli bardzo częste zmiany na stanowiskach, wywoływały wrażenie chaosu i nie ułatwiały prowadzenia skutecznej polityki.

$\mathrm{Na}$ temat Lavala nie zostawił polski minister wyrazistych przemyśleń, stwierdzając jedynie, iż polityk ten jest bardziej nuancé niż Paul-Boncour i Barthou ${ }^{18}$. Zdaje się, iż doceniał jego większy pragmatyzm niż u Barthou w podejściu do zagadnień bezpieczeństwa europejskiego. Nie mógł nie dostrzec wysiłków Lavala na rzecz zbliżenia Francji i Włoch, co na pewno odpowiadało zasadom ówczesnej polskiej racji stanu. Niemniej jego konto obciążała rola sygnatariusza paktu z Sowietami.

Z całą pewnością bardzo krytyczna była opinia polskiego ministra o Flandinie jako głównym - w optyce polskiej - „winowajcy” bezczynności Francji w krytycznych godzinach marca 1936 r., kiedy Hitler wprowadził armię do Nadrenii. Nie zachowała się wszakże żadna opinia Becka na temat tego polityka - z wyjątkiem rzuconej do Szembeka uwagi, iż jest to człowiek ,zupełnie bezczelny"19.

Nader wysoko cenił sobie Beck kontakty z Delbosem, o którym nadmienił we wspomnieniach, iż był to „,polityk rzetelny i uczciwy”20. Ogólnie nie mając zaufania do klasy politycznej III Republiki - wyróżnił w ten sposób tę osobistość Frontu Ludowego. Spotkawszy go w Cannes - skonstatował, iż ,ten głęboko kulturalny i rozumny człowiek nie dał jeszcze pełnego wyrazu w swojej pracy i należy we Francji do ludzi przyszłości”21. Delbos jawił się w oczach Becka przede wszystkim jako „zręczny dyplomata”. Nader wysoką ocenę tego polityka przekazał minister ambasadorowi von Moltkemu. Delbos stwierdził w grudniu 1937 r. - to ,„pierwszy francuski minister spraw zagranicznych, który rozumie i pojmuje polską politykę zagraniczną oraz jej szczególne interesy"22. Była to opinia wydatnie na wyrost, gdyż źródła francuskie nie upoważniają do tak entuzjastycznej opinii.

Nie powinno dziwić, iż bardzo źle wypowiadał się Beck o Benešu i Titulescu, o czym już było wspomniane ${ }^{23}$. Odzwierciedlało to wysoką temperaturę antagonizmu, jaki występował między nim a tymi oddanymi rzecznikami „,zbiorowego bezpieczeństwa” i „klientalnej" polityki wobec Francji oraz Sowietów.

Antypatia Becka do Beneša - i vice-versa - były w europejskim świecie dyplomatycznym znana. Czy jednak brała się z zazdrości o międzynarodową popularność czeskiego polityka, jak niekiedy sugeruje się w historiografii - nie jest łatwo rozstrzygnąć. Wydaje się, że dużo ważniejsze było przekonanie o nielojalności polityki czechosłowackiej, co potwierdziły pamiętne wypadki z 1919 i 1920 r., ale też i własne ministerialne doświadczenia Becka z czasów walki przeciw Paktowi Czterech, a zwłaszcza koncepcji Paktu Wschodniego. Choć konflikt Beck-Beneš był na pewno spersonalizowany, to jednak osadzony na podłożu sporu o urządzenie Europy Środkowej.

\footnotetext{
${ }^{18}$ DTJS, t. I, s. 283.

${ }^{19}$ DTJS, t. II, s. 94; notatka z 26 lutego 1936 r.

${ }^{20}$ J. Beck, Wspomnienia o polskiej polityce zagranicznej 1926-1939, s. 161.

${ }^{21}$ Ibidem, s. 168.

${ }^{22}$ PAAA, Botschaft Warschau, Karton 50, raport amb. von Moltke z 11 grudnia $1937 \mathrm{r}$.

${ }^{23} \mathrm{Nie}$ było to tajemnicą dla świata dyplomacji europejskiej. Otwarcie pisał o tym w raporcie z 4 maja $1938 \mathrm{r}$. Kennard do Foreign Office (TNA, Foreign Office 371, 21808, C. 4020/2470/55).
} 
Czeski historyk Jindrich Dejmek pisał, iż wrogość do Czechów przejął Beck od Piłsudskiego jako jego uczeń ${ }^{24}$. W rzeczywistości nie znajdujemy w źródłach śladów takich emocji w ustosunkowaniu do narodu, ale przede wszystkim krytykę teorii narodu czechosłowackiego i państwa Masaryka oraz Beneša, a zwłaszcza jego polityki zagranicznej. Bliższe prawdy wydaje się spostrzeżenie ambasadora Kennarda, iż u Becka negatywne usposobienie do Czechów jest zabarwione tym, iż osobiście nader nie lubi swego odpowiednika z Pragi ${ }^{25}$. Polski minister zresztą różnicował swoje ustosunkowanie do obydwu mężów stanu. Podkreślał, że Masaryk wypracował pewną koncepcję poprawy stosunków z Polską, natomiast Beneš nie, gdyż miał no sense of realities ${ }^{26}$.

Trudno o bardziej klarowne przeciwieństwo niż to, jakie tworzyli Beck i Beneš. Czechosłowacki polityki sam mówił o sobie, iż jego myślenie o polityce cechuje ,metodyczny racjonalizm kartezjański" ${ }^{27}$. Beck - ze swej strony - powtarzał, że ten, kto nie dostrzega imponderabiliów, nie jest realistą. Beneš był ,dyplomatycznym ideologiem”. Beck postrzegał politykę inaczej - właśnie jako służbę narodowym imponderabiliom.

Beck nie znosił Titulescu - z wzajemnością 28 . Jak się zdaje, nie bez znaczenia było to - iż rumuński polityk pokrzyżował mu (jeszcze jako wiceministrowi) plany doprowadzenia do jakiejś kompromisowej formuły paktu o nieagresji z Sowietami, którego Rumunia ostatecznie nie zawarła, nie chcąc w żaden sposób ominąć problemu Besarabii, a rząd w Moskwie nie chciał jurydycznie potwierdzić jej utraty. Dodajmy, iż zaangażowanie Becka w mediację dyplomacji polskiej między Moskwą a Bukaresztem było pierwszym jego znaczącym wystapieniem dyplomatycznym, jeszcze jako wiceministra spraw zagranicznych.

Jak wiadomo, Beck nie poznał osobiście Stalina. Nie zetknął się również z innymi czołowymi przywódcami ZSRR. Z polityków sowieckich spotykał się głównie z Litwinowem - na terenie międzynarodowym, przede wszystkim w Genewie. Z oczywistych przyczyn nie mogło być między nimi klimatu zaufania. Polskę i Związek Sowiecki dzieliło zbyt wiele. We wspomnieniach Beck przypisał swemu sowieckiemu partnerowi antypolski „uraz psychiczny tego człowieka - »Litwaka z pochodzenia «"29. Widział w nim „,naszego notorycznego nieprzyjaciela". Również i ten antagonizm nie był tylko skutkiem antypatii osobistych, lecz zasadniczych rozbieżności między Polską a ZSRR. W oczach Litwinowa polski minister spraw zagranicznych uosabiał to wszystko, przeciw czemu walczyła dyplomacja sowiecka - przede wszystkim bilateralizm i proniemieckość. „Beck używa starej metody dyplomatycznej, ukrywa myśl za słowami, a jego polityka stała się najbardziej zagadkową i wiarołomną" - powtarzał Litwinow ${ }^{30}$.

W Europie wiedziano o wybitnie złożonych stosunkach polsko-sowieckich, chociaż były one formalnie unormowane. Politykę polską - czytamy w jednym z memorandów

\footnotetext{
${ }^{24}$ J. Dejmek, Ministr Józef Beck a jeho zahranicni politika v pohledu ceskoslovenskych diplomatu 1932-1939, „Slovanske Historicke Studie” (Pocta Henrykovi Batowskemu), t. 23, Praha 1997, s. 111.

${ }^{25}$ Raport z 4 maja 1938 r., TNA, Foreign Office 371, 21808, C. 4020/2470/55.

${ }^{26}$ Kennard do Foreign Office, raport z 2 maja 1938 r., TNA, Foreign Office 371, 21808, C. 3741/2470/55.

${ }^{27}$ P. S. Wandycz, Twilight, s. 463.

${ }^{28}$ Kennard pisał, iż polski minister cierpi na srogą awersję do Titulescu. Zob. jego raport do Foreign Office z 2 maja 1938 r. (jak wyżej).

${ }^{29}$ J. Beck, Wspomnienia o polskiej polityce zagranicznej 1926-1939, s. 227.

${ }^{30}$ AWP RF, f. 5, op. 15, pap. 109, dok. 67; Litwinow do Dawtiana, instrukcja z 21 lutego 1935 r.
} 
Foreign Office - cechuje brak zaufania do Rosji, a do Litwinowa w szczególności ${ }^{31}$. Z pewnością znamienne jest jednak, że sowiecki ambasador Dawtian dochodził do przekonania, iż jest bardzo wątpliwe, czy jakikolwiek inny minister zamiast Becka byłyby ,wygodniejszy dla nas", czyli Sowietów ${ }^{32}$.

Z pewnością za czasów Becka jedną z ważniejszych pozycji w stosunkach międzynarodowych zajmowały faszystowskie Włochy. Polski minister gościł u Mussoliniego dopiero w marcu 1938 r. Wówczas też rozmawiał z ministrem Ciano - konserwatystą, który podobnie jak Beck wszedł do polityki włoskiej w bardzo młodym wieku ${ }^{33}$. W lutym $1939 \mathrm{r}$. gościł swego włoskiego odpowiednika po raz pierwszy i ostatni w Polsce; niestety nie zachowały się żadne relacje źródłowe o percepcji Mussoliniego i Ciano.

W zachowaniu Ciano Beck dostrzegał „teatralne śmiesznostki”, podkreślając, że dokładnie wykonuje on „instrukcje swego teścia” i jest jego porte-parole. Minister nie brał tego jednak za złe, pisząc nawet, że „,to już było w każdym razie dużo"34.

Podejrzenia francuskich kół politycznych o sympatie Becka do faszyzmu nie mają z całą pewnością oparcia na jakichkolwiek dowodach. I w tej sprawie minister podążał za Piłsudskim, który nie zalecał Polsce adaptacji włoskich wzorców.

Wysoką ocenę zyskał w oczach Becka szwedzki socjaldemokratyczny polityk Rikard Sandler. „Największe zrozumienie w tej pracy znajdowałem u najwybitniejszego może skandynawskiego polityka, szwedzkiego ministra spraw zagranicznych, p. Sandlera" stwierdził w swych wspomnieniach, dyktowanych w Rumunii ${ }^{35}$. Postrzegał go jako „bardzo poważnego partnera politycznego”. Beck doceniał jego odwagę, aby „oficjalnie odrzucić współpracę z międzynarodówką komunistyczną”. Myśleć można, iż decydowało tu ogólne uznanie Becka dla polityki szwedzkiej. Grało swoją rolę podobne podejście do Ligi Narodów, zwłaszcza w kwestii rozluźnienia zobowiązań wypływających z artykułu 16. jej Paktu $^{36}$.

Nadmiernie wysoką reputację przypisywał Beck następcy Titulescu Victorowi Antonescu jako ministrowi spraw zagranicznych. Powiedział o nim w roku 1940:

P. Antonescu zorientował się doskonale, że namiętności polityczne i ambicje osobiste p. Titulescu podważyły poważnie atmosferę między naszymi krajami. Ten zasłużony i doświadczony mąż stanu, powróciwszy - zdaje się po raz czwarty - na stanowisko ministra spraw zagranicznych, poprawnością i logicznością swego języka politycznego od razu przywrócił zdrowy stosunek między naszymi krajami ${ }^{37}$.

O nikim, poza Edenem, Beck nie wypowiedział słów tak jednoznacznie afirmatywnych. Rumuński polityk dostrzegł potrzebę czynienia gestów wobec polskiej narodowej dumy, gdyż Polacy to „najbardziej wrażliwi ludzie na świecie, o czym zapomnieli Francuzi”38.

\footnotetext{
${ }^{31}$ Memorandum Foreign Office na temat ogólnej sytuacji w Europie z 21 marca 1935 r., w związku z podróżą Edena do Warszawy i Moskwy, TNA, Foreign Office 371, 18896, C. 2480/465/55.

${ }^{32}$ AWP RF, f. 5, op. 15, pap. 109, dok. 68; Dniewnik Dawtiana, notatka z 8 listopada 1935 r.

${ }^{33}$ Galeazzo Ciano, urodzony w roku 1903, został szefem resortu spraw zagranicznych w roku 1936.

${ }^{34}$ J. Beck, Wspomnienia o polskiej polityce zagranicznej 1926-1939, s. 187.

${ }^{35}$ Ibidem, s. 193.

${ }^{36}$ P. Jaworski, Polska niepodległa wobec Skandynawii 1918-1939, Wrocław 2001, s. 75-76.

${ }^{37}$ J. Beck, Wspomnienia o polskiej polityce zagranicznej 1926-1939, s. 165.

${ }^{38}$ TNA, Foreign Office 371, 19964, C. 8463/8463/55; poseł R. Hoare do Edena, raport z 19 listopada $1936 \mathrm{r}$.
} 
Niemniej znaczenie Antonescu, będącego krótkotrwałym szefem resortu spraw zagranicznych swego kraju, niewątpliwie przecenił.

W swojej karierze spotkał Beck jugosłowiańskiego ministra spraw zagranicznych Milana Stojadinovicia, którego ocenił wysoko. Przypisywał mu dobre wyczucie realités des choses z powodu dojścia do porozumienia z Włochami, co zdawało się znacznie poprawiać położenie międzynarodowe Jugosławii ${ }^{39}$. Układ jugosłowiańsko-włoski z 25 marca 1937 r. (czyli pakt Stojadinović-Ciano) określił w rozmowie z ambasadorem von Moltkem jako rezultat oddziaływania ,niemiecko-polskiej szkoły układów” (deutsch-polnische Abkommen Schule) ${ }^{40}$.

II.

Słusznie zauważył Piotr Wandycz, że osobowość Becka odegrała znaczącą rolę w polskiej polityce zagranicznej i kształtowała jej percepcję za granicą, a przede wszystkim miała znaczenie w ukształtowaniu stosunku Zachodu do Polski. Czynnik ten zaważył na wizerunku Polski z pewnością w większym stopniu, niż w przypadku innych państw znaczyła jednostka, jaką jest minister spraw zagranicznych. Teza, iż politykę zagraniczną Polski w przemożnym stopniu kształtuje osobowość ministra Becka, należała do opinii najczęściej powtarzanych za granicą u kresu lat trzydziestych.

Złożony i na ogół krytyczny był wizerunek polskiego ministra w oczach partnerów cudzoziemskich.

Pierwsze oceny nowego polskiego ministra spraw zagranicznych, powstałe jesienią 1932 r., nie świadczą o optymistycznych rokowaniach kół zagranicznych w związku z jego nominacją. Beck jawił się jako człowiek ,,inteligentny i energiczny”, lecz „bez skrupułów i unrealiable" - jak uważano w brytyjskim Foreign Office. W brytyjskiej charakterystyce polskiego ministra nie pojawiło się zmyślone pomówienie o szpiegostwo, ale twierdzenie, że jako polski attaché wojskowy został ,przeniesiony” z powodu ,popełnienia kilku nieszczęsnych gaf'. Incydenty te sprawiły, że zachował ,bias against France”. Ma jako polityk ,personal vanity”, ale jest „essentially practical” i ma też „realistyczny, w jakiejś mierze oportunistyczny światopogląd" (outlook), co w oczach brytyjskiego dyplomaty nie było wadą ${ }^{41}$.

„Nie mogę wyobrazić sobie bardziej niepożądanej kombinacji jak panowie Beck i Szembek" - zauważył Collier, szef Departamentu Północnego. Duet ten jawił mu się jako przygotowanie do agresywnej polityki wobec Gdańska. Beck był przede wszystkim mniej pojednawczy i umiarkowany niż Zaleski. Ambasador brytyjski Erskine krytycznie oceniał ministra, pisząc o nim: ,,jego niemal wschodni sposób krążenia wokół tematu i ukrywania znaczenia myśli nie wywołuje zaufania ani nie ułatwia dochodzenia do porozumienia". Ale o tym, co zasadnicze w polityce polskiej, decyduje marszałek Piłsudski podkreślał brytyjski dyplomata ${ }^{42}$.

\footnotetext{
${ }^{39}$ Dnia 28 marca 1937 r. doszedł do skutku głośny pakt jugosłowiańsko-włoski (Stojadinović-Ciano).

${ }^{40}$ PAAA, Botschaft Warschau, Karton 50, raport amb. von Moltke z 11 grudnia 1937 r.

${ }^{41}$ Raport Kennarda „Leading personalities of Poland” z 30 czerwca 1939; TNA, Foreign Office 371, 23135, C. $10430 / 10430 / 55$.

${ }^{42}$ Erskine do Foreign Office, 9 listopada 1932 oraz do Colliera, 7 grudnia 1932 (TNA, Foreign Office 371, 16313, N. 6457/1472/55).
} 
Fundamentalne linie polityki polskiej całkowicie rozwijają się w umyśle Marszałka, który „,keeps his own counsel tak dalece, iż niemożliwe jest zgadnąć jego obecne intencje” - to zasadnicze przekonanie brytyjskich dyplomatów ${ }^{43}$. Takie opinie zniknęły oczywiście po śmierci Piłsudskiego.

Opinia o Becku jako „człowieku bez skrupułów” i „o wielkiej ambicji” - to stały motyw opinii zagranicznych, który kształtował jego wizerunek ${ }^{44}$. „Beck jest osobą, której appearance and manner, jak również styl of his utterances" nieuchronnie wywołuje podejrzenia co do jego dobrej woli ${ }^{45}$. Porównywanie Becka z Zaleskim wypadało z reguły wyraźnie niekorzystnie dla niego.

Pytając o percepcję Becka w oczach zagranicznych partnerów i świadków epoki, trzeba podkreślić przewagę ocen negatywnych, krytycznych, pozbawionych sympatii. Przegrana przez Polskę walka o przetrwanie między dwoma totalitarnymi mocarstwami sprawiła, że w relacjach przedstawicieli europejskiego świata polityki trudno było o zrozumienie jego polityki.

Eden, Duff-Cooper, Gafencu, czy Burckhardt - którzy zostawili nam charakterystykę polskiego ministra, kreślili ją w sposób dla niego niekorzystny, przy czym uwypuklali nie tyle wadliwość założeń polityki polskiej, ile rzeczywiste i rzekome wady jego charakteru i sposobu prowadzenia dyplomacji.

Powyższe opinie nie powinny jednak przesłonić faktu, że do roku 1938 zebrał Beck sporo bardzo pozytywnych ocen swojej dyplomacji, zwłaszcza po śmierci marszałka Piłsudskiego.

Charakteryzując polskiego polityka, ambasador brytyjski uważał, że zdobył on pozycję ,pomyślnego ministra spraw zagranicznych” (succesful foreign minister) i zrobił wiele, aby „wzmóc prestiż swego kraju za granicą"46. W listopadzie 1936 r. Kennard doceniał u Becka „umiejętne prowadzenie spraw zagranicznych" ${ }^{47}$. Ten sam dyplomata porównywał go do jugosłowiańskiego polityka Stojadinovicia ${ }^{48}$. „...) wszystkim się zdaje, że stawia na właściwego konia" - pisał o Becku szwedzki dyplomata, Sven Grafsroem. Widział W nim również rzecznika stosowania „twardych metod" ${ }^{49}$.

„Jego reputacja jako zdolnego i skutecznego ministra spraw zagranicznych stale rosła” - pisał o Becku brytyjski ambasador w Warszawie, doceniając jego ,unikanie kłopotliwych zobowiązań" (avoiding embarrassing commitments) ${ }^{50}$. Opinie podobnie korzystne wyrażali o polskim ministrze spraw zagranicznych politycy amerykańscy. Polski ambasador w Waszyngtonie Jerzy Potocki 18 stycznia 1938 znalazł u Roosevelta ,uznanie dla Polski z powodu utrzymania jej wyjątkowego stanowiska na Wschodzie Europy i niepoddania się Polski ekstremistycznym wpływom" ${ }^{51}$. Sekretarz Stanu Cordell Hull chwalił Becka jako

${ }^{43}$ Minutes wewnętrzne Foreign Office o „liniach polityki polskiej” z 4 lutego 1935 (TNA, Foreign Office, 18896, C. 1253/465/55).

${ }^{44}$ Kennard do Simona, raport z 1 lutego 1935, TNA, Foreign Office, 18887, C. 822/87/55.

${ }^{45}$ Minutes wewnętrzne Foreign Office o ,liniach polityki polskiej” z 4 lutego $1935 \mathrm{r}$.

${ }^{46}$ Raport Kennarda „Leading personalities of Poland” z 30 czerwca 1939.

${ }^{47}$ Kennard do Foreign Office, 1 listopada 1936, TNA, Foreign Office 371, 19957, C. 7905/49/55.

${ }^{48}$ Kenanrd do Sargenta, list z 8 marca 1938, TNA, Foreign Office 371, 21807, C. 1739/1320/55.

${ }^{49}$ S. Grafstroem, Polskie stronice, s. 58 (notatka z 25 sierpnia 1938 r.).

${ }^{50}$ TNA, Foreign Office 371, 21806, C. 261/261/55 (raport „Leading Personalities of Poland” z 1 stycznia 1938).

${ }^{51}$ IPMS, MSZ, A. 11. 49/3 (list prywatny). 
„wyjątkowo zdolnego męża stanu, który zdołał utrzymać równowagę w morzu totalitaryzmu"52. Niełatwo rozsądzić, ile w tej wypowiedzi było dyplomatycznej kurtuazji, a ile rzeczywistych przekonań amerykańskiego polityka.

W lutym 1938 r. w Cannes Winston Churchill, wówczas poseł do Izby Gmin i stanowczy krytyk polityki appeasementu, o Becku wyrażał się z uznaniem - jeśli zaufać notatce polskiej z ich rozmowy:

Znalazł on w nim uzasadniony wyraz trosk męża stanu, odpowiedzialnego za stanowisko Polski wobec wypadków zewnętrznych. Churchill skorzystał z tej sposobności, by powiedzieć, że z ust Edena słyszał o Panu Ministrze zdanie harmonizujące z jego (Churchilla) pozytywną oceną exposé. Eden zarówno ceni zdanie Ministra, jak ma zaufanie do motywów, które nim powodują $q^{53}$.

Również ambasador Potocki, po rozmowie z ambasadorem Williamem Bullittem - raportował 12 kwietnia 1938 r., iż odnosił się on ,z wielką admiracją odnośnie do polityki zagranicznej prowadzonej przez Pana Ministra"54.

Ekwilibrystyka Becka w prowadzeniu polityki polskiej miała nielicznych wprawdzie, ale niekryjących podziwu obserwatorów. To ,impossible tight-rope walk” (,niemożliwy taniec linoskoczka") między Niemcami a Rosją, jak określił politykę ministra Becka brytyjski dyplomata Harold Butler - dyrektor Międzynarodowego Biura Pracy ${ }^{55}$.

Opinie francuskie były dużo mniej entuzjastyczne.

Pochodząca z 8 maja 1935 r. stosunkowo obszerna i tajna notatka o Becku, którą przygotowano we francuskim MSZ, zawierała streszczenie podstawowych faktów biograficznych polskiego polityka. Dokument określał temperament ministra jako ,ambitieux et autoritaire”. Nie brakuje mu inteligencji i energii - ale można zapytać, czy zna mentalność zachodnią mimo swego pobytu w Paryżu na początku lat dwudziestych. „Inteligencja i finezja" (finese) powinny mu wystarczyć. Beck jawił się jako polityk bardzo młody, ambitny, pragnący odegrać wielką rolę w stosunkach międzynarodowych. „Jeśli ma sympatie do Włoch faszystowskich i Niemiec, które w wielu sprawach podziwia, musi zdawać sobie sprawę jako oficer Legionów, że wpływy tych państw podrywają położenie Polski” - czytamy w tym dokumencie. Polityka Becka jawiła się w Paryżu jako polityka niezawisłości w myśl dewizy „Polonia fara da se”. Miała ona utwierdzić swobodę Polski i pokazać, że „odgrywa ona na Wschodzie Europy rolę wielkiego mocarstwa, na tyle silnego, aby nie zajmować roli drugoplanowej w sojuszu z Francją. Można jednak być pewnym, że większość opinii publicznej w Polsce niepokoi się poważnie, czy ta skierowana przeciwko nam polityka prestiżu nie narazi (compromettait) na szwank sojuszu z Francją" - czytamy w notatce francuskiej. Przypisując Beckowi ,talent manewrowania”, autorzy kończyli swoje rozważania stwierdzeniem, iż trudno ocenić, czy dostrzeże ograniczenia swych możliwości ${ }^{56}$.

Chociaż polityka zagraniczna Polski miała proste zasady, co do których trudno zgłosić wątpliwości, w opinii zagranicznej utrwalił się wizerunek jej twórcy jako człowieka nie-

${ }^{52}$ Raport amb. Potockiego (Waszyngton) do Becka, 18 stycznia 1938, AAN, MSZ, sygn. 4980.

${ }^{53}$ Notatka amb. E. Raczyńskiego, IPMS, Ambasada Londyn, A. 12.49/WB/2.

${ }^{54}$ Z. Landau, J. Tomaszewski, Monachium 1938, Warszawa 1986, s. 82-85.

${ }^{55}$ H. Butler, The Lost Peace, London 1942, s. 162.

${ }^{56}$ AMAE, Europe 1918-1940, Pologne, vol. 298. Notatka Pod-Dyrekcji Europy (niepodpisana). 
szczerego, prowadzącego jakąś podwójną grę. Duff-Cooper, czyli brytyjski pierwszy lord admiralicji, po rozmowie z Beckiem w Gdyni odniósł wrażenie, iż jego umysł jest „,pokręcony do granic" (tortuous in the extreme). Na opinii takich ludzi jak Loyd George czy Beck nie można polegać - to jedna $\mathrm{z}$ myśli brytyjskiego polityka, którą zawarł on w liście do lorda Halifax ${ }^{57}$.

Rumuński dyplomata i poseł w Warszawie Constantin Visoianu wyodrębnił piętnaście trwałych cech polskiej polityki zagranicznej. Wśród nich nade wszystko akcentował „bilateralizm" i programową niechęć do Ligi Narodów. Działania dyplomacji Polski na rzecz zbudowania bloku Międzymorza, czyli „Trzeciej Europy”, wydawały mu się zupełnie nierealne. Oskarżał też Polskę o przyjmowanie niemieckiego punktu widzenia na sprawy międzynarodowe, co notabene było bezpodstawne ${ }^{58}$.

Przede wszystkim myśl, że Beck jest gwarantem kursu na rzecz ugody z Niemcami, pojawiała się jako zasadniczy komentarz do jego roli w polityce polskiej. Przekonaniu temu towarzyszyło stwierdzenie, iż „linia 26 stycznia 1934 r.” w stosunkach polsko-niemieckich nie ma poparcia społeczeństwa polskiego, a może nawet prowadzona jest wbrew niemu, czemu sprzyja autorytarny ustrój wewnętrzny. Armia polska ma świadomość, że ,potencjalnym wrogiem głównym” (main potential enemy) są Niemcy - czytamy w notatkach urzędników brytyjskiego Foreign Office z maja 1936 r. Ale jak długo Beck będzie trwał na stanowisku, polityka polska się nie zmieni ${ }^{59}$.

Świadomi tego stanu rzeczy byli sami Niemcy. Jak wynika z brytyjskich dokumentów dyplomatycznych, jeden z dyplomatów ambasady Rzeszy w Warszawie mówił wprost: „(...) wiemy, iż Beck is all right, ale reszta kraju nas nienawidzi” (but the rest of the country hates us $)^{60}$.

Beck jest proniemiecki, dowodził ambasador Kennard. Jednak teza ta ma tylko jedną podstawę. Postępuje on tak, gdy pragnie nie uczynić czegokolwiek, aby nie obrazić (to offend) Berlina ${ }^{61}$.

W brytyjskich aktach dyplomatycznych spotkamy opinie o Becku jako człowieku, który „osobiście nie lubi Francuzów” ${ }^{2}$. Miała ona niestety licznych propagatorów - nie tylko w Londynie.

Oceny powojenne - kreślone z dystansu czasu - otwiera opinia Edena; polityk ten podkreślając, iż Beck darzył go przyjaźnią, zdecydował się na próbę jego charakterystyki w swych powojennych wspomnieniach. Pisał:

W sposobie bycia nie zachowywał prostolinijności i wywierał nieco złowieszcze wrażenie. Zrozumienie, o co mu chodzi, wymagało nieraz wysiłku i cierpliwości. Nie lubił Francuzów, co

\footnotetext{
${ }^{57}$ Rozmowa Becka z Duff-Cooperem, TNA, Foreign Office 371, 21807, C. 8719/2168/55. List Duff-Coopera do lorda Halifax z 8 sierpnia 1938 r. (błąd datacji: w liście mamy lipiec).

${ }^{58}$ Cyt. za A. Zieliński, Rumuńskie materiały do dziejów stosunków polsko-rumuńskich w latach trzydziestych XX wieku, „Studia z Dziejów ZSRR i Europy Środkowej”, t. 20, 1984, s. 214-215.

${ }^{59}$ Takie poglądy przypisywało francuskiej opinii publicznej brytyjskie Foreign Office w związku z raportem ambasady brytyjskiej w Paryżu z 18 maja 1936, Minutes na marginesie, TNA, Foreign Office 371, 19956, C. $3714 / 49 / 55$.

${ }^{60}$ Chargé d'affaires w Warszawie C. Norton do Stragan, list z 13 lipca 1938, TNA, Foreign Office 371, 21807, C. $7191 / 2168 / 55$.

${ }^{61}$ List Kennarda do Colliera z 6 listopada 1935, TNA, Foreign Office 371, 18887, C. 7548/465/55.

${ }^{62}$ Aveling do Wigrama, list z 8 maja 1935, TNA, Foreign Office 371, 18887, C. 3829/87/55.
} 
było niebezpieczne dla jego kraju, chociaż usprawiedliwiało go przekonanie, że francuska potęga wojskowa jest przesadzona. W pierwszej fazie ministerialnej kariery jego sąd był często błędny, a uprzedzenia prowadziły na manowce. Nie miał dostatecznego doświadczenia ani osobistego dostatecznego autorytetu i wykonywał we wszystkim rozkazy marszałka. Pociągnęło to za sobą dwa kapitalne błędy: zbytnie zaufanie do słów nazistów i zbytnie uleganie antypatii do Czechów, którym zagrażało to samo co Polsce niebezpieczeństwo. (...) Gdy nadszedł czas próby, przynosząc klęskę kalkulacjom i polityce Becka, nie zawiodło jego męstwo, podobnie jak nie zawiodło męstwo jego bohaterskiego kraju, którego nie mogliśmy ocalić ani na początku wojny, ani w jej ostatniej fazie ${ }^{63}$.

Halvdan Koht - minister spraw zagranicznych Norwegii, który poznał Becka, goszcząc w Warszawie i podejmując go w Oslo, zwrócił uwagę na jasność myślenia polskiego ministra. Po lekturze Dernier rapport scharakteryzował go w następujących słowach: ,był człowiekiem impulsywnym, obdarzonym silną wolą. Posiadał zmysł bystrej orientacji i lekceważył tych, którzy nie potrafili myśleć tak jasno, jak on sam. Wcale zresztą tego nie ukrywał" ${ }^{64}$.

Najmocniej ,czarna legenda” Becka znalazła wyraz u polityków Czechosłowacji, sowieckiej Rosji i we Francji ${ }^{65}$.

Ideologia reżimu Becka w tym kraju [Polsce - M.K.] była nieodległa od doktryny politycznej nazistowskich Niemiec i tak zainfekowała pewną część narodu polskiego, że chociaż Polacy znajdowali się w śmiertelnym niebezpieczeństwie, to nie mogli zrozumieć, że istnieją pewne zobowiązania wynikające z moralności politycznej, których państwo nie może naruszyć w pewnych okolicznościach. Reżim Becka naruszył te zobowiązania wobec Czechosłowacji w r. 1938. Było to tak samo złe, jeśli nie gorsze niż agresja reżimu Hitlera przeciwko nam

- stwierdził Beneš już po II wojnie światowej ${ }^{66}$.

„Grand figure dominait la politique polonaise, celle du Maréchal Pitsudski” - pisał francuski premier Flandin w swe książce Politique polonaise. Zaleskiego zastapił Beck. Pierwszy z nich prowadził polityke ,z dużą finezją i autorytetem, zwłaszcza w Lidze Narodów”. Régime des colonels wprowadził w polskiej polityce zagranicznej zaborczego ducha ,,podboju nowych terytoriów”. Kierował on Polskę przeciw postanowieniom Paktu Ligi Narodów ${ }^{67}$.

Rumuński minister spraw zagranicznych Grigore Gafencu, wspominając swoją podróż do Warszawy wiosną 1939 r., poświęcił Beckowi dłuższy wywód. Podkreślał, iż przeceniał on możliwości swego kraju. Pisał, że rosły jego osobiste ambicje, ale też niewątpliwie rosły ,ambicje narodu”, który odzyskał własne państwo ${ }^{68}$.

Siedmioletnie zasiadanie w Pałacu Brühlowskim w charakterze szefa przyniosło przede wszystkim liczne kontakty i współpracę z korpusem dyplomatycznym akredytowanym w Warszawie.

${ }^{63}$ A. Eden, Pamiętniki, t. 1: W obliczu dyktatorów, Warszawa 1970, s. 135.

${ }^{64}$ A. Bielnicki, Halvdan Koht i Józef Beck, „Komunikaty Instytutu Bałtyckiego” (Gdańsk), z. 27/28, 1978, s. 77.

${ }^{65}$ Szczegółowe stadium Jindricha Dejmka dotyczy postrzegania dyplomacji Becka, a nie jego osobowości: J. Dejmek, Ministr Józef Beck a jeho zahranicni politika v pohledu ceskoslovenskych diplomatu 1932-1939 (jak wyżej).

${ }^{66}$ E. Beneš, Postwar Czechoslovakia, „Foreign Affairs”, vol. 24, 1945-1946, s. 402.

${ }^{67}$ P.-E. Flandin, Politique française 1918-1940, Paris 1947, s. 117.

${ }^{68}$ G. Gafencu, Ostatnie dni Europy. Podróż dyplomatyczna w 1939 roku, Warszawa 1984, s. 18. 
Tu oczywiście szczególną rolę odgrywali ambasadorowie francuscy.

Laroche nie miał zaufania do Becka, ale nie prowadził otwartej walki z ministrem spraw zagranicznych państwa, w którym był akredytowany. Wyjechał z Polski zaraz po śmierci Piłsudskiego. Precedensowo udekorowany Orderem Orła Białego, został ambasadorem w Brukseli. Noël, który go zastąpił - w ocenie jego brytyjskiego odpowiednika Kennarda - był „młodzieńczym człowiekiem” (youngish man) i ze wszech miar jawił się „całkowitym przeciwieństwem” Laroche’a. Nie był dyplomatą de carrière. „Trudno wierzyć - zauważył Kennard - że odbuduje on tu prestiż Francji”" ${ }^{9}$. I miał rację.

O ile relacje z Larochem kształtowały się pod znakiem urzędniczej poprawności, a uwieńczyła je dekoracja ambasadora Orderem Orła Białego, chociaż stosunki polsko-francuskie weszły w fazę dużego deficytu wzajemnego zaufania - to relacje z jego następcą Noëlem trzeba opisać jako rodzaj dyplomatycznej anomalii.

U Becka pierwsze oceny działań Noëla nie były bynajmniej negatywne. Jesienią $1935 \mathrm{r}$. minister podkreślał, że nie poszedł on śladami swego poprzednika, Laroche’a, i nie spiskuje z opozycją. Stara się natomiast wyrobić sobie sympatie w kołach rządowych. Rozwój wypadków zaprzeczył jednak tym wrażeniom. Gra polityczna francuskiego ambasadora przeciw Beckowi stała się niestety faktem. Minister nie mógł nie być tego nieświadom, skoro mówiono o tym wciąż na nowo w cudzoziemskich ministerstwach spraw zagranicznych ${ }^{70}$.

Wraz z nominacją do Warszawy ambasadora Leona Noëla w roku 1935, szanse „wyrównania" stosunków polsko-francuskich i odbudowania atmosfery wzajemnego zaufania uległy poważnemu osłabieniu. Oczywiście dalece nieprawdziwe byłoby thumaczenie wszystkiego, co działo się w stosunkach Warszawa-Paryż, wpływem osobowości tego ambasadora. Jednak jeśli przyjąć, iż podstawowym zadaniem dyplomaty, pełniącego misję zagraniczna, jest usiłowanie zrozumienia polityki prowadzonej przez kraj, w którym ją sprawuje - to z zadania tego Noël się nie wywiązywał. Osobista animozja w stosunkach z Beckiem $\mathrm{i}$,mentalność prokonsula" (mentalité proconsulaire) przesłaniały mu to, co istotne w polskiej polityce zagranicznej ${ }^{71}$.

Swoimi wspomnieniowymi publikacjami Noël walnie przyczynił się do utrwalenia negatywnego stereotypu Becka w historiografii zachodniej. O ile pierwsza książka Agresja niemiecka przeciw Polsce jest nacechowana pewną oględnością, to druga - zatytułowana Polonia Restituta jest przykładem skrajnie tendencyjnej publicystyki historycznej ${ }^{72}$. W historii dyplomacji właściwie nie ma przypadku, aby ambasador danego państwa wyjawił tyle antypatii do ministra spraw zagranicznych państwa akredytowania.

„W Polonia Restituta jest tyle jadu, zapiekłych niechęci i antybeckowkiego kompleksu, że trudno jest się oprzeć pokusie strawestowania znanego powiedzenia: tout comprendre, c'est tout pardonner mais rien comprendre, ce n'est rien pardonner"73. Zaledwie

${ }^{69}$ Raport Kennarda dla Edena „Heads on Foreing Missions i Poland” z 1 stycznia 1938, TNA, Foreign Office 371, 21798, C. 12/12/55.

${ }^{70}$ Kennard pisał, iż Noël odwzajemnia negatywne uczucia Becka do Francji (TNA, Foeign Office, 21808, C. 4020/2470/55). Raport z 4 maja 1938 r.

${ }^{71}$ Wspominana powyżej książka Yvesa Beauvois (Leon Noël. De Laval à de Gaulle via Pétain, Paris 2001) jest rzetelnym omówieniem roli tej postaci w stosunkach polsko-francuskich. Określenia mentalité proconsulaire użył Beauvois z całą świadomością (s. 434).

${ }^{72}$ L. Noël, Polonia Restituta. La Pologne entre deux mondes, Paris 1984.

${ }^{73}$ A. M. Cienciała, P. S. Wandycz, ,Polonia Restituta”- czyli Noël redivivus, ,Zeszyty Historyczne”, z. 72, 1985 , s. 158 . 
niewielki gest niechęci ze strony Francuzów w roku 1932 mógł, zdaniem Noëla, sprawić, że Piłsudski by Becka nie mianował ministrem spraw zagranicznych ${ }^{74}$. Nawet wygląd polskiego ministra był po prostu „odrażający”75. Niestety wielu historyków akademickich czerpie z rewelacji Noëla, traktując je jako źródło historyczne ${ }^{76}$.

Trudno coś bliżej powiedzieć o niemieckim ambasadorze von Moltkem w percepcji Becka. Dyplomata ten służył w Warszawie od 1931 r. i asystował w procesie polsko-niemieckiego odprężenia po roku 1933. Zapewne najwięcej zadowolenia przyniosło Beckowi pismo gratulacyjne ambasadora Niemiec von Moltkego, datowane na 2 listopada 1937 r. i napisane w języku dyplomacji, czyli po francusku, na które minister odpowiedział cztery dni później, stwierdzając, iż „dzięki niemu dokonał się postęp w stosunkach naszych dwóch krajów poprzez układ z 26 stycznia 1934 r. w pierwszej linii"’77. Charakteryzując Moltkego, powiedzieć trzeba o jego złożonej sytuacji osobistej. Trafnie ujął to ambasador brytyjski Kennard, notując, iż dyplomata ten ma „mało sympatii do polityki swego rządu w wielu kierunkach, najbardziej w Gdańsku", ale stosuje daleko posuniętą dyskrecję ${ }^{78}$. Dyplomata pruskiej szkoły musiał patrzeć z niechęcią na pojednawczą politykę Hitlera wobec Polski.

Doskonałe stosunki ukształtował sobie Beck z ambasadorem amerykańskim Drexel-Biddlem, którego raporty potwierdzają, że polski minister darzył go dużym zaufaniem ${ }^{79}$. W amerykańskim dyplomacie Beck widział powiernika swoich ważniejszych ocen polityki międzynarodowej i przemyśleń na jej temat.

Dużą aktywność i dobre zrozumienie realiów Polski przejawiał pierwszy za czasów Becka ambasador włoski, Bastianini. Poświadczają to jego raporty kierowane do Palazzo Chigi w Rzymie ${ }^{80}$. Jego następca, Arone Di Valentino - nie miał żywotności swego poprzednika. Ambasada Italii - jeśli odwołać się do oceny brytyjskiego ambasadora - pełniła raczej ,insignificant role here" ${ }^{\text {" }}$.

Pozostaje z pewnością interesujące, iż mimo braku zaufania do polityki Stolicy Apostolskiej na wysoką ocenę zapracował w oczach Becka ostatni nuncjusz watykański w Warszawie, Filippo Cortesi. „(...) prałat wybitny, dyplomata doświadczony, znany z umiejętności wyegzekwowania od kleru danego kraju silnej dyscypliny w stosunku do Stolicy Apostolskiej" - to cechy tej osobistości, na które wskazał Beck w swoich wspomnieniach ${ }^{82}$.

Jeszcze jedna ogólna refleksja, którą wysnuł Beck o swoich partnerach zagranicznych, jest godna uwagi. Jego zdaniem, z perspektywy Polski na większe zaufanie zasługiwała

\footnotetext{
${ }^{74}$ L. Noël, Polonia Restituta, s. 76.

${ }^{75}$ Ibidem, s. 86.

${ }^{76}$ Przykładem pozostaje Donald Cameron Watt (mamy na myśli jego książkę How War Came. The Immediate Origins of the Second World War 1938-1939, London 1989, s. 69-70).

${ }^{77}$ PAAA, Botschaft Warschau, Karton 50.

${ }^{78}$ Raport roczny Kennarda, ,Heads on Foreing Missions in Poland” z 1 stycznia 1938, TNA, Foregin Office 371, 21798, C. 12/12/55.

${ }^{79}$ Poland and the Coming of the Second World War. The Diplomatic Papers of A. J. Drexell-Biddle Jr., United States Ambassador to Poland 1937-1939, (ed.) introd. by P. V. Cannistraro, E. D. Wynot, T. P. Kovaleff, Columbus/Ohio 1976.

${ }^{80}$ Analizuje te zainteresowania i opinie Bastianiniego J. W. Borejsza; zob. J. W. Borejsza, Mussolini byt pierwszy..., Warszawa 1979, s. 181-242.

${ }^{81}$ Raport roczny Kennarda „Heads on Foreing Missions in Poland” z 1 stycznia 1938 r.

${ }^{82}$ J. Beck, Wspomnienia o polskiej polityce zagranicznej 1926-1939, s. 174.
} 
nowa generacja polityków w Europie, bowiem z nimi łatwiej się porozumieć, gdyż nie pamiętają oni Europy sprzed roku 1914, na mapie której państwa polskiego nie było. Oni łatwiej przyjmują nowe koncepcje polityki międzynarodowej ${ }^{83}$.

Z całą pewnością oceny zagraniczne są zawsze jakimś odzwierciedleniem reputacji danego polityka w świecie. Nie zawsze jednak przekładają się one na jego skuteczność. Polityk cieszący się w międzywojennej Europie znaczącym autorytetem, tj. Beneš - nie zdołał ocalić swego kraju jesienią 1938 r. w obliczu dyktatu monachijskiego. Nie pomogły mu wysokie notowania zagranicznych sfer opiniotwórczych. Silnie krytykowany za granicą Beck zdołał jednak osiągnąć umiędzynarodowienie konfliktu swego kraju z Niemcami. Nie znaczy to oczywiście, że opinie obce są bez znaczenia. Niemniej potrzeba zawsze dystansu do nich, zwłaszcza w naszych ocenach, formułowanych ex post.

\section{Skróty}

AAN - Archiwum Akt Nowych w Warszawie AMAE - Archives du Ministère des Affaires Etrangères AWP RF - Archiw Wnieszniej Politiki Rossijskoj Fedieracji, Moskwa DTJS - Diariusz i teki Jana Szembeka (1935-1945)

IPMS - Archiwum Instytutu Polskiego i Muzeum im. gen. Władysława Sikorskiego w Londynie PAAA - Politisches Archiv des Auswärtigen Amts, Berlin

TNA - The National Archives in London, Foreign Office

\section{Bibliografia}

Archiwa

Archiwum Akt Nowych w Warszawie, Ministerstwo Spraw Zagranicznych Archives du Ministère des Affaires Etrangères (Paris La Courneuve)

Archiw Wnieszniej Politiki Rossijskoj Fedieracji (Moskwa)

Archiwum Instytutu Polskiego i Muzeum im. gen. Władysława Sikorskiego w Londynie

Politisches Archiv des Auswärtigen Amts (Berlin), Botschaft Warschau

The National Archives (London), Foreign Office

Źródła publikowane

Diariusz i teki Jana Szembeka (1935-1945), t. 1 (1935), oprac. T. Komarnicki, Londyn 1964.

Diariusz i teki Jana Szembeka (1935-1945), t. 2 (1936), oprac. T. Komarnicki, Londyn 1965.

Eden A., Pamiętniki, t. 1: W obliczu dyktatorów, Warszawa 1970.

Flandin P.-E., Politique française 1918-1940, Paris 1947.

Jędrzejewicz W., Cisek J., Kalendarium życia Józefa Piłsudskiego 1867-1935, t. IV: 1927-1935, Kraków-Lomianki 2007.

Landau Z., Tomaszewski J., Monachium 1938, Warszawa 1986.

${ }^{83}$ DTJS, t. II, s. 71; notatka z 4 lutego 1936 r. 
Noël L., Polonia Restituta. La Pologne entre deux mondes, Paris 1984.

Poland and the Coming of the Second World War. The Diplomatic Papers of A. J. Drexell-Biddle Jr., United States Ambassador to Poland 1937-1939, (ed.) introd. by P. V. Cannistraro, E. D. Wynot, T. P. Kovaleff, Columbus/Ohio 1976.

Raczyński E., W sojuszniczym Londynie. Dziennik ambasadora Edwarda Raczyńskiego 1939-1945, Warszawa 1990.

Starzeński P., Trzy lata z Beckiem, przedm. napisał i przypisami opatrzył B. Grzeloński, Warszawa 1991.

Opracowania (monografie i artykuły)

Batowski H., Między dwiema wojnami 1919-1939. Zarys historii dyplomatycznej, Kraków 1988.

Beauvois Y., Leon Noël. De Laval à de Gaulle via Pétain, Paris 2001.

Beck J., Wspomnienia o polskiej polityce zagranicznej 1926-1939, oprac. A. M. Cienciała, Warszawa-Kraków 2015.

Beneš E., Postwar Czechoslovakia, „Foreign Affairs”, 1945-1946, vol. 24.

Bielnicki A., Halvdan Koht i Józef Beck, „Komunikaty Instytutu Bałtyckiego” (Gdańsk), 1978, z. $27 / 28$.

Borejsza J. W., Mussolini byt pierwszy..., Warszawa 1979 (wyd. 2, 1987).

Broszat M., Zweihundert Jahre deutsche Polenpolitik, Frankfurt am Main 1981 (wyd. 1: 1963).

Butler H., The Lost Peace, London 1942.

Cienciała A. M., Wandycz P. S., „Polonia Restituta”- czyli Noël redivivus, „Zeszyty Historyczne”, 1985, z. 72, s. 147-159.

Dejmek J., Ministr Józef Beck a jeho zahranični politika v pohledu československych diplomatů 1932-1939, „Slovanské Historické Studie” (Počta Henrykovi Batowskemu), t. 23, Praha 1997.

Gafencu G., Ostatnie dni Europy. Podróż dyplomatyczna w 1939 roku, thum. S. Rembek, Warszawa 1984.

Grafström S., Polskie stronice. Dziennik od 5 lipca 1938 do 6 grudnia 1939 roku, wybór i tłum. J. Lewandowski, A. N. Uggla, Warszawa 1996.

Jaworski P., Polska niepodległa wobec Skandynawii 1918-1939, Wrocław 2001.

Roberts F., Dealing with Dictators. The Destruction and Revival of Europe 1930-1970, London 1991.

Stroński S., Wierność Józefa Becka, „Wiadomości”, 27 kwietnia 1952.

Wandycz P., O polityce zagranicznej Polski międzywojennej, „Niepodległość” (Nowy Jork-Londyn), 1989, t. 22 (po wznowieniu).

Wandycz P., Polska wobec lokarneńskiej polityki Brianda, [w:] P. Wandycz, Z dziejów dyplomacji, Londyn 1988.

Wandycz P., The Twilight of French Eastern Alliances 1926-1936: French-Czechoslovak-Polish Relations from Locarno to the Remilitarization of the Rhineland, Princeton 1988.

Watt D. C., How War Came. The Immediate Origins of the Second World War 1938-1939, London 1989.

Zernack K., Polen und Russland. Zwei Wege in der europäischen Geschichte, Berlin 1994.

Zieliński A., Rumuńskie materiały do dziejów stosunków polsko-rumuńskich w latach trzydziestych XX wieku, „Studia z Dziejów ZSRR i Europy Środkowej”, 1984, t. 20, s. 214-215.

Marek Kornat (ur. 1971), historyk, profesor nauk humanistycznych od r. 2015. Pracuje w Instytucie Historii PAN i wykłada na Wydziale Prawa i Administracji UKSW. Zasadniczo zajmuje się historią polskiej dyplomacji i stosunków międzynarodowych w XX wieku oraz dziejami polskiej myśli politycznej i sowietologii. Wydał m.in. książki: Polska 1939 roku wobec paktu Ribbentrop- 
-Mołotow (2002); Bolszewizm - totalitaryzm - rewolucja - Rosja. Poczatki sowietologii i studiów nad systemami totalitarnymi w Polsce (1918-1939) (2003-2004); Adam Jerzy Czartoryski. Essai sur la Diplomatie (2011); Polityka zagraniczna Polski 1938-1939. Cztery decyzje Józefa Becka (2012); Polen zwischen Hitler und Stalin. Studien zur polnischen Außenpolitik in der Zwischenkriegszeit (2012); Wacław Grzybowski. Ambasador w Moskwie (1936-1939). Biografia polityczna (2016). 